\title{
DAMPAK PROGRAM PEMBERDAYAAN MODEL DESA KONSERVASI TERHADAP KEMANDIRIAN MASYARAKAT: KASUS DI TAMAN NASIONAL BUKIT BARISAN SELATAN LAMPUNG (Impact of Empowerment Program on Conservation Village Model toward community Sustainability: Case at Bukit Barisan Selatan National Park,Lampung)
}

\author{
Ristianasari ${ }^{1}$, Pudji Muljono ${ }^{2}$, \& Darwis S. Gani ${ }^{3}$ \\ ${ }^{1}$ Pusat Penyuluhan Kehutanan Badan Penyuluhan dan Pengembangan SDM Kementerian Kehutanan \\ Telp. (021) 572-228, e-mail: fondristahf@yahoo.com \\ ${ }^{2}$ Dosen Ilmu Penyuluhan Pembangunan IPB Bogor \\ ${ }^{3}$ Guru besar Ilmu Penyuluhan Pembangunan IPB Bogor
}

Diterima 22 Februari 2013, direvisi 19 Maret 2013, disetujui 31 Mei 2013

\begin{abstract}
Deforestation and degradationcaused by encroachment area are the greatest threats to conservation of Bukit Barisan Selatan National Park (BBSNP). Meanwbile, many aspects related with social phenomena such as what drives people to fullfil their need can'tbe separated from its management. Empowering communities is not just to stop the damage but directed as an effort to increase community selfreliance. This term refers to sense of willingness to be able to develop their knowledge, awareness and skills for welfare and conservation in the field of ecological, economic, and social-cultural.Conservation Vilage Model is a form of community empowerment-based economy and conservation conducted at BBSNP. Understanding its process and impact are the most important step related to conservationin BBSNP. This study has two main objectives that include the following: (1) to analyze the impact of community empowerment through MDK; (2) to analyze the factors correlated with effectiveness of community empowerment. This study was conducted at Sukaraja and Kubu Perabu, Lampung, as a buffer zone and enclave of BBSNP from February to November 2012. The study was design using survey method. The analysis used in this study were: (1) descriptive statistic by using distribution frequency and Mann Whitney non parametric test; (2) inferencial statistic by using Rank Spearman correlation. The result could be summarized as follows: community sustainabilitywas categoryzed in good level; sosio-demographic characteristic,interaction and access to BBSNP and empowerment approach have very significant and positive correlation with community self-reliance. Thisimpactcan be increased by improving the understanding of community characteristics, theirinteraction and acess to BBSNP and appliying the most appropriate approach.
\end{abstract}

Keywords: Community empowerment, Conservation Village Model, South Bukit Barisan National Park.

\begin{abstract}
ABSTRAK
Deforestasi dan degradasi akibat perambahan kawasan merupakan permasalahan terbesar dalam pengelolaan kawasan Taman Nasional Bukit Barisan Selatan (TNBBS). Sementara itu, berbagai aspek terkait kepentingan masyarakat untuk memenuhi kebutuhannya serta pengaruhnya terhadap perilaku konservasi mereka tidak dapat dipisahkan dalam pengelolaannya. Pemberdayaan bukan sekedar untuk menghentikan kerusakan kawasan, tetapi harus memperhatikan upaya pelestarian kawasan dalam aspek ekologi, ekonomi, dan sosial budaya. Pemberdayaan juga diarahkan untuk meningkatkan kemandirian masyarakat yang mengarah pada kemauan dalam mengembangkan kesadaran, pengetahuan dan keterampilan untuk kesejahteraan. Model Desa Konservasi (MDK) merupakan program pemberdayaan masyarakat berbasis ekonomi dan konservasi yang dilaksanakan TNBBS. Memahami proses dan dampaknya terhadap masyarakat merupakan langkah dasar dan strategis dalam upaya konservasi TNBBS. Penelitian ini bertujuan untuk: (1) menganalisis kegiatan pemberdayaan masyarakat MDK di TNBBS; dan (2) menganalisis faktor-faktor yang berhubungan dengan efektifitas pemberdayaan masyarakat MDK di TNBBS. Desain penelitian menggunakan metode survey. Penelitian dilakukan di Pekon Sukaraja dan Pekon Kubu Perahu sebagai daerah penyangga dan enclave kawasan TNBBS. Analisis Menggunakan statistik deskriptif dan inferensial. Hasil penelitian menunjukkan bahwa karakteristik sosio-demografi, interaksi serta akses terhadap sumber daya dan pendekatan pemberdayaan mempunyai korelasi sangat signifikan dengan kemandirian masyarakat.

Upaya meningkatkan pemahaman terhadap karakteristik masyarakat dan menerapkan pendekatan pemberdayaan yang sesuai dengan kondisi masyarakat merupakan hal penting dan relevan dalam mewujudkan kemandirian sebagai dampak pemberdayaan MDK di TNBBS.
\end{abstract}

Kata kunci: Model Desa Konservasi, pemberdayaan masyarakat, Taman Nasional Bukit Barisan Selatan

Dampak Program Pemberdayaan Model Desa Konservasi terhadap Kemandirian Masyarakat: ..... (Ristianasari, Pudji Muljono, \& Darwis S. Gani) 


\section{PENDAHULUAN}

Hampir seluruh kawasan konservasi di Indonesia berada dalam pola interaksi yang kuat dengan masyarakat di sekitarnya. Pada umumnya masyarakat yang tinggal di sekitar kawasan konservasi termasuk dalam kategori miskin (Santosa, 2004). Data empiris menunjukkan bahwa jumlah penduduk Indonesia yang tinggal di desa di dalam dan sekitar hutan yang kehidupannya bergantung pada sumber daya hutan adalah sekitar 48,8 juta orang, dimana 10,2 juta orang diantaranya tergolong miskin (Ditjen RLPS, 2007 di acu dalam Kemenhut, 2011a). Salah satu penyebabnya dikarenakan terbatasnya akses terhadap kegiatan pembangunan dan pemanfaatan sumber daya alam (Kemenhut, 2011b). Kondisi inilah yang menimbulkan adanya konflik antara kepentingan masyarakat dengan kepentingan konservasi.

Taman Nasional Bukit Barisan Selatan (TNBBS), sebagai kawasan konservasi terbesar ketiga di Sumatera dengan status, potensi dan fungsi penting, sering dihadapkan pada benturan berbagai kepentingan dengan masyarakat berkaitan dengan akses terhadap sumberdaya alam yang dimilikinya. Sejak tahun 1985-1999 kawasan TNBBS telah kehilangan lebih dari $28 \%$ dari luas totalnya (Kinnaird et al., 2003). Pola ekstensifikasi lahan, pencurian kayu, dan eksploitasi flora fauna telah menyebabkan deforestasi dan degradasi kawasan. Dari total luas kawasan 356.800 ha, TNBBS telah mengalami pembukaan tutupan hutan seluas 60.296 ha, dimana 60.286 ha diantaranya diakibatkan perambahan oleh \pm 14.703 orang perambah (BTNBBS, 2011). Laju kehilangan tutupan lahan mencapai $22,5 \%$ dari total luas kawasan selama 10 tahun terakhir (BTNBBS, 2010). Penanganan serius dan tepat diperlukan bukan hanya untuk mempertahankan status sebagai tapak warisan dunia, tetapi lebih pada mempertahankan kawasan sebagai penyangga fungsi kehidupan tanpa mengabaikan keberadaan masyarakat.

Dalam banyak kasus, masyarakat jarang dimunculkan dalam pengelolaan kawasan konservasi (Chase et al., 2004 diacu dalam Guthiga, 2008), meskipun masyarakat tersebut merupakan kunci keberhasilan pengelolaan kawasan konservasi (Wiggins et al., 2004; Robertson dan Lawes 2005). Pengelolaan Taman Nasional saat ini tidak bisa dipisahkan dari masyarakat yang bermukim di sekitar kawasan (Borrini-Feyerabend et al., 2004).
Masyarakat yang tinggal di sekitar hutan dapat menjadi pilar bagi terciptanya pengelolaan hutan lestari. Pickering dan Owen (1994) dan Welford (1996) yang diacu oleh Agbogidi dan Ofuoku (2009) mengemukakan bahwa daya dukung lingkungan semakin berkurang akibat kerusakan oleh manusia. Hal ini telah menyebabkan terancamnya berbagai bentuk kehidupan, untuk itu perlu pendidikan dan penyadaran bagi masyarakat. Salah satu cara terbaik dalam pengelolaan hutan adalah menciptakan kesadaran masyarakat lokal tentang pentingnya keterlibatan mereka dalam proses tersebut (Agbogidi et al., 2005). Hal itu tidak dapat dilakukan tanpa proses penyuluhan salah satunya dalam bentuk pemberdayaan. Penekanan yang sama mengenai pentingnya masyarakat dan kegiatan pemberdayaannya diamanatkan dalam Undang-Undang Nomor 41 Tahun 1999 tentang Kehutanan, Permenhut No. P.16/Menhut-II/2011 tentang Pedoman Umum Program Nasional Pemberdayaan Masyarakat Mandiri (PNPM) Sektor Kehutanan dan PP No. 28 Th 2011 tentang Pengelolaan Kawasan Suaka Alam dan Kawasan Pelestarian Alam.

Pemberdayaan masyarakat di sekitar kawasan konservasi telah dilakukan sejak tahun 1993 melalui pengembangan daerah penyangga namun belum berhasil secara optimal. Pendekatan pemberdayaan yang selama ini dilakukan terbukti hanya menghasilkan perilaku sasaran yang apatis dan perubahan perilaku yang tidak permanen. Pemberdayaan dengan pendekatan kearah persuasif dan partisipatif diharapkan akan lebih efektif menghasilkan keberdayaan serta kemandirian. Untuk merealisasikannya, pemberdayaan masyarakat dilakukan melalui Model Desa Konservasi (MDK). Saat ini, MDK telah dilaksanakan oleh 77 (tujuh puluh tujuh) Unit Pelaksana Teknis (UPT) Direktorat Jenderal Perlindungan Hutan dan Konservasi Alam (PHKA) Kementerian Kehutanan baik oleh Balai Konservasi Sumberdaya Alam (BKSDA) maupun Taman Nasional di kurang lebih 133 desa di dalam dan sekitar kawasan (Dephut, 2009).

Pemberdayaan masyarakat Model Desa Konservasi (MDK) merupakan upaya dalam meningkatkan akses timbal balik peran masyarakat dan fungsi kawasan. Model Desa Konservasi (MDK) merupakan desa yang dijadikan model/contoh bagi desa lain di sekitar kawasan konservasi dalam upaya pemberdayaan masyarakat 
di sekitar kawasan konservasi, dengan memperhatikan aspek konservasi, sosial, ekonomi, dan budaya masyarakat setempat. MDK bertujuan untuk mengurangi ketergantungan masyarakat terhadap kawasan, meningkatkan kemandirian dalam pemanfaatan potensi yang dimiliki. Dengan demikian, melalui program pemberdayaan MDK diharapkan akan terjadi peningkatan kesejahteran masyarakat dan kelestarian kawasan melalui kegiatan yang telah disepakati sehingga dapat menjamin keseimbangan ekologi, ekonomi dan sosial budaya. Kegiatan MDK telah dilaksanakan di TNBBS sejak tahun 2006. Kegiatan MDK difokuskan di dua desa/pekon, yaitu Pekon Sukaraja (daerah penyangga) dan Pekon Kubu Perahu (wilayah enclave).

Berdasarkan ulasan di atas, kajian yang diperlukan adalah bagaimana memahami proses dan dampak pemberdayaan masyarakat melalui program MDK untuk dapat menjadi dasar bagi upaya konservasi terutama dalam merancang pemberdayaan yang tepat untuk diterapkan. Permasalahan yang ingin diperoleh jawabannya adalah bagaimanakah pemberdayaan MDK yang dilakukan di TNBBS dan faktor apa saja yang berhubungan dengan kemandirian masyarakat sebagai dampak program pemberdayaan tersebut. Selanjutnya, tujuan penelitian ini adalah untuk menganalisis dampak kegiatan pemberdayaan masyarakat MDK di TNBBS dan faktor-faktor yang berhubungan dengan pemberdayaan masyarakat MDK tersebut.

\section{METODE PENELITIAN}

\section{A. Rancangan Penelitian}

Penelitian dilakukan menggunakan metode survey dengan tujuan mencari data dan fakta mengenai faktor-faktor yang berhubungan dengan dampak pemberdayaan Model Desa Konservasi (MDK) di TNBBS terhadap perilaku konservasi masyarakat. Penelitian ini menguraikan fakta-fakta dan informasi yang diperoleh di lapangan, baik secara langsung maupun tidak langsung untuk mendapat gambaran secara faktual dan akurat mengenai fakta-fakta tersebut, hubungan antara fenomena yang diteliti, menguji hipotesis, membuat makna serta implikasi dari hasil yang diperoleh.

Variabel/peubah penelitian terdiri dari variabel bebas (independent variable) dan variabel tidak bebas (dependent variable). Berdasarkan telaah pustaka yang dilakukan, secara skematis kerangka berpikir penelitian yang memuat berbagai variabel penelitian disajikan pada gambar berikut:

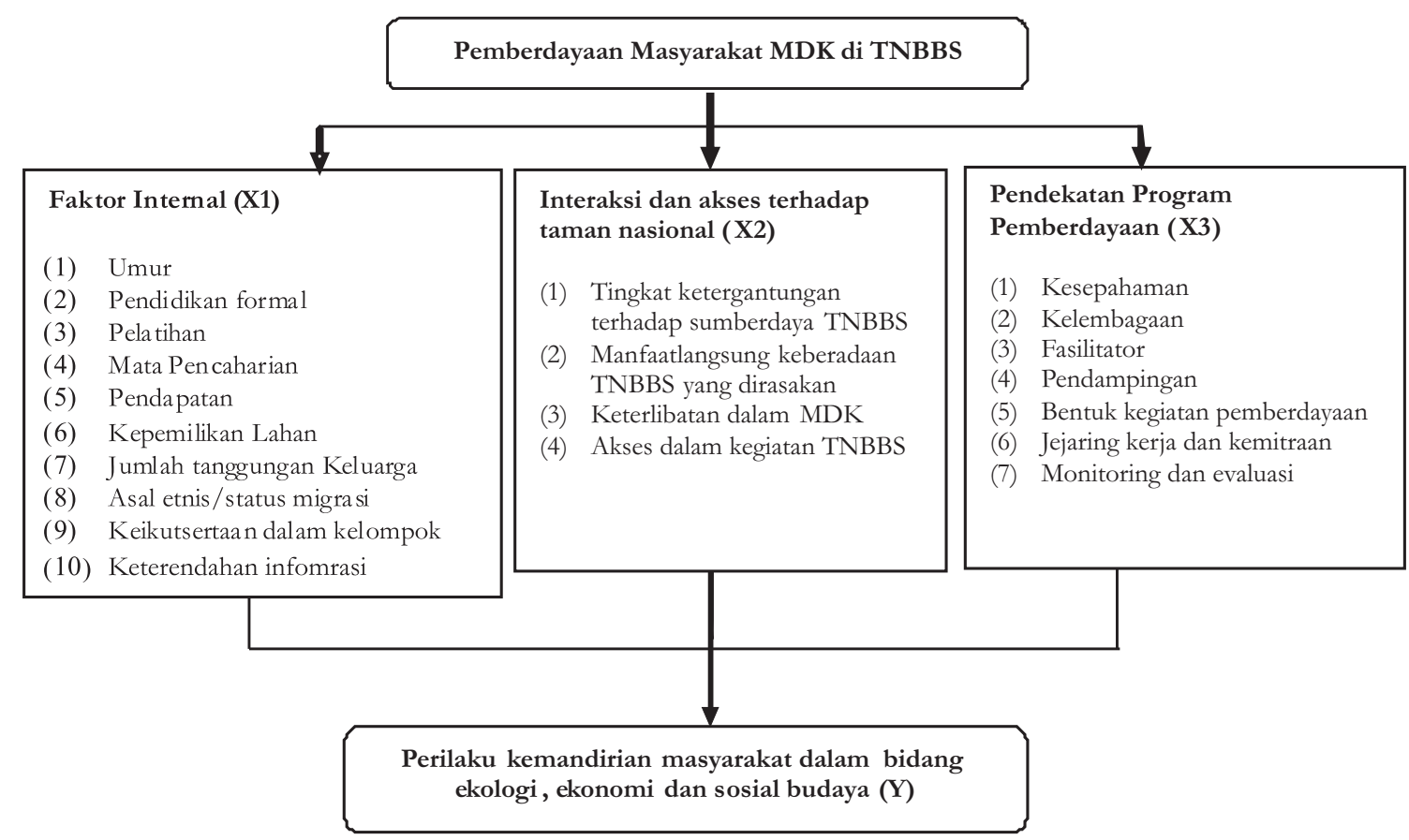

Gambar 1. Variabel-variabel dalam kerangka berpikir penelitian

Figure 1. The variables in the research framework. 
Penelitian dilakukan di Taman Nasional Bukit Barisan Selatan (TNBBS), yaitu di Pekon Sukaraja Kecamatan Semaka Kabupaten Tanggamus dan Pekon Kubu Perahu Kecamatan Balik Bukit Kabupaten Lampung Barat sebagai lokasi pemberdayaan MDK. Pelaksanaan penelitian mulai dari survei pendahuluan, penyusunan kerangka sampling, penyusunan kuesioner, uji coba kuesioner, pengumpulan data primer dan sekunder, pengolahan dan analisis data dilakukan selama sembilan bulan mulai dari bulan Pebruari sampai dengan Oktober 2012.

\section{B. Responden (Populasi dan Sampel)}

Responden penelitian adalah masyarakat sasaran program pemberdayaan Model Desa Konservasi (MDK) di TNBBS di pekon/desa lokasi kegiatan pemberdayaan, yaitu Pekon Sukaraja (daerah penyangga) dan Pekon Kubu Perahu (enclave). Total sampel berdasarkan rumus Slovin diperoleh 104 responden dengan rincian 67 responden di Pekon Sukaraja dan 37 responden di Pekon Kubu Perahu. Unit analisis dalam penelitian ini adalah petani anggota kelompok penerima manfaat program pemberdayaan MDK.

\section{Jenis dan Cara Pengumpulan Data}

Jenis data adalah data primer dan sekunder. Data primer berupa hasil kuesioner dan wawancara. Data sekunder berupa dokumen-dokumen tentang gambaran umum kawasan TNBBS dan data desa tempat dilaksanakan penelitian serta data terkait yang mendukung. Data di peroleh melalui pengamatan di lapangan (observasi), kuesioner, wawancara serta dokumentasi.

\section{Analisis Data}

Data hasil penelitian dianalisis dengan statistik deskriptif dan inferensial. Untuk menjelaskan secara kualitatif, data dikelompokkan dalam bentuk tabulasi distribusi frekuensi. Untuk mengetahui perbedaan nilai rata-rata dua populasi yang mewakili lokasi penelitian, digunakan uji nonparametrik yaitu uji beda Mann-Whitney. Sedangkan untuk mengetahui hubungan antar variabel digunakan analisis korelasi Rank Spearman. Uji ini digunakan untuk mengetahui hubungan masing-masing variabel dengan rumus / persamaan:

$$
\begin{aligned}
& \mathrm{N} \\
& 6 \sum \mathrm{di}^{2} \\
& \text { Keterangan: } \\
& \mathrm{i}=1 \\
& \mathrm{r}_{\mathrm{s}}=1 \text { - } \\
& =\text { Koefisien korelasi Spearman } \\
& \mathrm{d}_{\mathrm{i}}=\text { Selisih antar jenjang } \\
& \mathrm{n}=\text { Banyaknya sampel }
\end{aligned}
$$

Analisis statistik dilakukan dengan menggunakan perangkat statistik Statistical Product and Service Solutions (SPSS) versi 20.0

\section{HASIL DAN PEMBAHASAN}

\section{A. Kondisi dan Karakteristik Responden di Lokasi Penelitian}

Pekon Sukaraja dan Pekon Kubu Perahu, sebagai lokasi pemberdayaan Model Desa Konservasi memiliki berbagai potensi yang layak untuk dikembangkan. Kondisi lokasi penelitian secara rinci sebagaimana disajikan dalam Tabel1.

Hasil penelitian karakteristik sosio-demografi menunjukkan bahwa sebagian besar masyarakat peserta program pemberdayaan $(85,6 \%)$ termasuk dalam kategori usia sangat produktif, berpendidikan sangat rendah setingkat sekolah dasar (58,7 persen) dan atau rendah setingkat SLTP $(21,2$ persen), serta tidak pernah atau jarang mengikuti pelatihan (75 persen). Sebagian besar masyarakat adalah pendatang dari Jawa (70,2 persen), bermata pencaharian sebagai petani (83,7 persen) dengan kepemilikan lahan dan penghasilan yang umumnya relatif rendah.

Masyarakat peserta pemberdayaan di Sukaraja cenderung lebih aktif dalam kelompok dibandingkan dengan Kubu Perahu. Hal ini dapat dipahami karena sebagian besar masyarakat Sukaraja merupakan petani pemilik lahan, sehingga mereka mempunyai tanggungjawab lebih besar terhadap lahan mereka terkait dengan harapan untuk memperoleh informasi terutama tentang bagaimana mengolah lahan dengan lebih baik untuk meningkatkan produktifitas dan pendapatan. Sementara itu, keterdedahan informasi berkaitan dengan upaya yang dilakukan responden dalam mencari informasi melalui berbagai media yang dapat mendorong perilaku positif berada dalam kondisi seimbang antara kategori rendah $(37,5 \%)$ dan tinggi $(38,5 \%)$. 
Tabel 1. Kondisi dan Potensi Pekon Sukaraja dan Pekon Kubu Perahu

Table 1. Sukaraja and Kubu Perahu as Conservation Village Model location

\begin{tabular}{|c|c|c|}
\hline Jenis Potensi (type of potention) & Sukaraja & Kubu Perahu \\
\hline $\begin{array}{l}\text { Letak Wilayah } \\
\text { (Locationof Region) }\end{array}$ & Kec.Semaka, Kab. Tanggamus, lampung & Kec. Balik Bukit, Kab. Lampung Barat, Lampung \\
\hline $\begin{array}{l}\text { Jumlah penduduk } \\
\text { (Population) }\end{array}$ & \pm 3431 jiwa & \pm 1941 jiwa \\
\hline $\begin{array}{l}\text { Mata pencaharian } \\
\text { (livelibood) }\end{array}$ & Mayoritas petani pemilik lahan & Mayoritas petani penggarap \\
\hline $\begin{array}{l}\text { Lanskap } \\
\text { (landscape) }\end{array}$ & $\begin{array}{l}\text { Lanskap berbukit, daerah pertanian dan } \\
\text { permukiman. }\end{array}$ & $\begin{array}{l}\text { Lanskap pegunungan rendah, daerah pertanian, } \\
\text { pemukiman }\end{array}$ \\
\hline $\begin{array}{l}\text { Tipe ekosistem } \\
\text { (Type of ecosystem) }\end{array}$ & $\begin{array}{l}\text { Hutan Hujan Bukit yang relatif masih asli, } \\
\text { habitat penting bagi jenis-jenis tumbuhan } \\
\text { unik dan langka }\end{array}$ & $\begin{array}{l}\text { Hutan hujan pegunungan tengah yang relatif masih asli. } \\
\text { Merupakan habitat penting bagi berbagai jenis anggrek } \\
\text { alam dan berbagai jenis burung. }\end{array}$ \\
\hline $\begin{array}{l}\text { Jenis vegetasi (flora) } \\
\text { (Type of vegetation) }\end{array}$ & $\begin{array}{l}\text { Terdapat jenis langka dan dilindungi yaitu } \\
\text { Bunga Rafflesia (Rafllesia sp), Bunga } \\
\text { Bangkai (Amorphophallus sp) }\end{array}$ & $\begin{array}{l}\text { Terdapat sedikitnya } 59 \text { jenis anggrek alam. Dua di } \\
\text { antaranya merupakan jenis yang dilindungi, yaitu Anggrek } \\
\text { Hitam (Gramatophlum sp) dan Anggrek Bulan Sumatera } \\
\text { (Phalaenotsis sumatranus) }\end{array}$ \\
\hline $\begin{array}{l}\text { Jenis fauna } \\
\text { (Type of fauna) }\end{array}$ & $\begin{array}{l}\text { Terdapat jenis fauna langka dan } \\
\text { dilindungi yaitu Harimau dan Badak } \\
\text { Sumatera }\end{array}$ & $\begin{array}{l}\text { Terdapat sedikitnya } 136 \text { jenis burung, seperti Rangkong } \\
\text { (Buceros sp) dan Kuau (Argusianus argus). Terdapat } \\
\text { sedikitnya } 49 \text { jenis mamalia, diantaranya siamang } \\
\text { (Hylobates syndactyllus), owa (Hylobates agilis) dan simpai } \\
\text { (Presbytis melalophos) dan mamalia besar, seperti beruang } \\
\text { madu (Helartos malayanus), gajah sumatera (Elephas } \\
\text { maximus sumatranus). }\end{array}$ \\
\hline $\begin{array}{l}\text { Wisata } \\
\text { (Tourism) }\end{array}$ & $\begin{array}{l}\text { Pemandangan perairan Teluk } \\
\text { Semangka, sungai dan hutan. Wilayah } \\
\text { ini sangat potensial bagi wisata alam, } \\
\text { berkemah, foto hunting, pengamatan } \\
\text { flora dan fauna. Di Sukaraja Atas, } \\
\text { terdapat beberapa obyek ekowisata } \\
\text { yaitu air terjun bumi perkemahan, } \\
\text { sarana out-bound, dan pengembangan } \\
\text { museum ekowisata (arboretum flora } \\
\text { dan fauna) }\end{array}$ & $\begin{array}{l}\text { Pemandangan indah strata tajuk hutan hujan pegunungan } \\
\text { yang masih asli, hawa sejuk dan segar, juga penjelajahan } \\
\text { hutan, pengamatan flora dan fauna, foto hunting, } \\
\text { berkemah, memancing, dan rekreasi air terjun yaitu } \\
\text { Sepapa Kanan }(20 \mathrm{~m}) \text { dan Sepapa Kiri }(60 \mathrm{~m}) \text {. Di Kubu } \\
\text { Perahu, mengalir sebuah sungai utama, yaitu Way } \\
\text { Sindalapai dengan ratusan anak sungai. Sungai-sungai } \\
\text { mengalir relatif stabil karena didukung banyaknya flora } \\
\text { penutup tanah dan belum terganggunya air tanah dangkal } \\
\text { sebagai sumber mata air. }\end{array}$ \\
\hline $\begin{array}{l}\text { Hasil hutan non kayu } \\
\text { (Non timber forest products) }\end{array}$ & Bambu, madu & Bambu, air, anggrek \\
\hline
\end{tabular}

Hasil penelitian faktor interaksi dan akses terhadap taman nasional menunjukkan bahwa ketergantungan terhadap taman nasional sebagian besar berada dalam kategori rendah yang berarti bahwa mereka tidak selalu tergantung pada kawasan dalam memenuhi kebutuhannya. Namun demikian, terdapat perbedaan nyata di kedua lokasi, masyarakat di Kubu Perahu mempunyai ketergantungan yang lebih tinggi terhadap kawasan. Sebagian besar masyarakat peserta pemberdayaan MDK merasakan manfaat langsung keberadaan taman nasional. Namun demikian, keterlibatan sebagian besar masyarakat (68\%) dalam program pemberdayaan MDK masih sangat rendah. Demikian juga dengan akses terhadap TNBBS, sebagian besar berada dalam kategori rendah.

Pendekatan pemberdayaan MDK terdiri dari kesepahaman, kelembagaan, fasilitator, pendampingan, bentuk kegiatan pemberdayaan, pengembangan jaringan kerja dan monitoring serta evaluasi. Berdasarkan hasil penelitian, kesepahaman termasuk dalam kategori rendah, hal ini berarti sebagian besar masyarakat peserta program pemberdayaan belum memahami tentang kegiatan MDK. Demikian pula dengan kelembagaan, dimana belum terdapat aturan-aturan yang jelas mengenai MDK baik di tingkat kelompok maupun Pekon serta belum ada lembaga pendukung lain yang berperan secara signifikan di dalamnya. Dalam hal penyuluh/fasilitator, sebagian besar masyarakat menyatakan bahwa fasilitator telah mempunyai kemampuan memadai. Namun demikian, masyarakat Kubu Perahu menilai bahwa penyuluh belum mempunyai kemampuan memadai dalam membangun kedekatan hubungan, fasilitasi membangun kemitraan, kemampuan teknis dan memberi saran atau masukan yang bermanfaat bagi mereka. Hal ini berkaitan dengan 
penilaian masyarakat terhadap proses pendampingan, dimana pendampingan di Sukaraja berjalan lebih baik. Bentuk kegiatan, pengembangan jaringan kerja dan monitoring evaluasi dalam pemberdayaan MDK di kedua pekon baik Sukaraja maupun Kubu Perahu juga berada dalam kategori rendah. Belum terjadi kesesuaian antara kebutuhan, hasil yang diharapkan dan kondisi lokasi dengan bentuk kegiatan pemberdayaan yang dilaksanakan.

\section{B. Pelaksanaan Program Pemberdayaan}

Menurut Page dan Czuba (1999), secara umum, pemberdayaan adalah proses multi-dimensi sosial yang membantu orang mendapatkan kontrol atas kehidupan mereka sendiri. Dalam perspektif lingkungan, pemberdayaan mengacu pada pengamanan akses terhadap sumberdaya alam dan pengelolaannya secara berkelanjutan (Riyanto, 2005). Selama ini pemberdayaan dimaknai sempit oleh berbagai pihak, sehingga pendekatan pemberdayaan diterjemahkan terbatas pada bantuan yang bersifat material (Herawati, 2012). Pendekatan pemberdayaan yang bersifat top down dimana masyarakat dianggap sebagai obyek, terbukti tidak mampu memberdayakan masyarakat, masyarakat tidak menjadi mandiri tetapi justru tergantung pada program-program pemberdayaan. Idealnya pemberdayaan mampu mengubah sasaran baik secara individu, kelompok maupun masyarakat dari kondisi tidak berdaya ke kondisi berdaya dan bermuara pada kondisi mandiri (Sumardjo, 2012). Masyarakat desa hutan yang sejahtera adalah masyarakat yang mandiri dan mampu berfungsi meningkatkan kesejahteraannya, memelihara ketertiban sosial dan kelestarian lingkungannya (Effendi et al., 2007). Ciri yang terlihat dari masyarakat mandiri adalah adanya kapasitas untuk mengembangkan dan menerapkan pengaturanpengaturan yang arif dalam pengelolaan hutan (Andri, 2002 diacu dalam Effendi et al., 2007).

\section{Dampak Program Pemberdayaan terhadap Kemandirian Masyarakat}

Sebagai masyarakat yang tinggal di sekitar kawasan konservasi, kemandirian dalam mengembangkan perilaku di bidang ekologi sangat penting. Pada umumnya masyarakat mengetahui bahwa taman nasional merupakan kawasan yang dilindungi. Masyarakat juga menyetujui akan pentingnya melestarikan kawasan. Namun demikian, masyarakat masih sulit untuk mengaplikasikan dalam hal tindakan, yang berarti bahwa dengan adanya pengetahuan, persepsi dan sikap yang baik tidak selalu memunculkan tindakan yang sesuai. Tindakan untuk menjaga dan melestarikan kawasan tidak selalu muncul dari inisiatif masyarakat sendiri, tetapi perlu didorong dan diarahkan oleh pihak lain. Selain itu masyarakat perlu merasakan adanya keuntungan bagi mereka.

Kemandirian dalam mengembangkan perilaku dibidang ekonomi dimaksudkan agar masyarakat mempunyai pengetahuan, persepsi dan sikap serta kemampuan dalam meningkatkan ekonomi tanpa merusak kawasan. Sebanyak 56 persen responden termasuk dalam kategori baik dan sangat baik. Dengan demikian tidak dapat dipungkiri bahwa masih banyak (44 persen) masyarakat mempunyai kemandirian ekonomi dalam kategori sangat rendah dan atau rendah. Meskipun secara umum masyarakat mempunyai sikap dan persepsi baik terhadap cara-cara dalam meningkatkan pendapatan tanpa merusak kawasan, namun mereka belum mengetahui bagaimana meningkatkan pendapatan dengan memanfaatkan potensi dan peluang yang mereka miliki. Hal inilah yang menyebabkan sikap dan persepsi tersebut belum sejalan dengan tindakan dalam kemandirian ekonomi karena terbatasnya sarana prasarana, modal, dan jaringan kerja.

Pemberdayaan MDK, diharapkan juga mampu mendorong masyarakat untuk mengembangkan perilaku kemandirian di bidang sosial budaya, dalam hal ini adalah ciri kehidupan bermasyarakat yang positif dan menunjang ke arah peningkatan kesejahteraan masyarakat serta kelestarian kawasan. Masyarakat pada umumnya setuju akan pentingnya mengembangkan potensi yang dimiliki, menaati aturan yang ada berkaitan pemanfaatan hutan tanpa merusaknya, bekerjasama dan beradaptasi dengan perubahan yang terjadi di sekitar mereka. Namun demikian, sebagian besar masyarakat belum mengetahui bagaimana caranya sehingga berimplikasi pada kurangnya tindakan ke arah tersebut. Dari hasil uji beda, terdapat perbedaan nyata dalam kemandirian ekologi dimana masyarakat peserta pemberdayaan MDK di Sukaraja cenderung mempunyai kemandirian yang lebih baik dalam bidang tersebut. Dengan demikian dapat dikatakan bahwa pemberdayaan MDK di Sukaraja mempunyai hasil yang lebih positif. 


\section{Hubungan karakteristik sosio-demografi dengan kemandirian masyarakat}

Hubungan karakteristik sosio-demografi dengan kemandirian masyarakat disajikan dalam tabel berikut.

Hasil penelitian sebagaimana terangkum dalam tabel di atas menjelaskan bahwa umur, mata pencaharian, dan jumlah tanggungan keluarga tidak berkorelasi dengan dampak pemberdayaan (kemandirian masyarakat). Pendidikan formal, pelatihan, pendapatan, kepemilikan lahan, asal etnis, keikutsertaan dalam kelompok dan keterdedahan informasi mempunyai korelasi (signifikan dan atau sangat signifikan) dengan kemandirian. Tingkat pendidikan akan berimplikasi terhadap pengetahuan, sedangkan pelatihan pada dasarnya berkaitan erat dengan peningkatan kapasitas masyarakat sehingga dapat mengelola kegiatan dengan lebih baik. Lahan merupakan aset sumberdaya, berkaitan dengan kemandirian, kepemilikan lahan akan mengurangi ketergantungan terhadap kawasan hutan. Kemandirian sebagai dampak pemberdayaan juga didorong oleh keikutsertaan dalam kelompok dan keterdedahan informasi. Masyarakat yang telah lama terlibat dalam kegiatan pemberdayaan dan aktif dalam kelompok cenderung mempunyai kemandirian yang lebih baik, sedangkan informasi, dapat membuka wawasan dan mendorong untuk membuka diri terhadap perubahan yang ditawar- kan, dalam hal ini program pemberdayaan.

Kondisi masyarakat dengan asal etnis berbeda menyebabkan mereka memiliki referensi tata nilai yang berbeda pula, dan hal ini akan menyebabkan perilaku bervariasi terhadap sumberdaya alam taman nasional. Kubu Perahu merupakan enclave, dimana masyarakat telah ada sebelum kawasan ditetapkan sebagai taman nasional. Ketergantungan yang kuat dengan kawasan berkaitan dengan pemenuhan kebutuhan, paling tidak akan mempengaruhi mereka dalam memandang kawasan, bukan saja sebagai kawasan dilindungi tetapi juga berkaitan dengan pemenuhan kebutuhan dan akses mereka yang semakin terbatas, sedangkan di Sukaraja, meskipun merupakan etnis pendatang, tetapi mereka telah tinggal cukup lama di daerah tersebut, bahkan sejak lahir. Mereka merasa sebagai masyarakat setempat dan mempunyai tanggung jawab sama terhadap lingkungan. Dengan perkembangan yang ada, masyarakat etnis asli justru terdorong untuk melakukan perambahan dalam kawasan karena melihat kehidupan pendatang yang lebih sejahtera.

\section{Hubungan interaksi dan akses terhadap taman nasional dengan kemandirian masyarakat}

Interaksi dan akses masyarakat terhadap taman nasional merupakan faktor penting dalam mengukur dampak pemberdayaan. Hal ini berkaitan dengan bagaimana kecenderungan

Tabel 2. Hubungan/korelasi karakteristik sosio-demografi dengan kemandirian

Table 2. Relation of socio-demographic characteristics toward sustainability

\begin{tabular}{|c|c|c|c|c|}
\hline \multirow{2}{*}{$\begin{array}{l}\text { Sub Variabel } \\
\text { (Sub Variables) }\end{array}$} & \multirow{2}{*}{$\begin{array}{l}\text { Ekologi } \\
\text { (Ecology) }\end{array}$} & \multicolumn{3}{|c|}{$\begin{array}{l}\text { Koefisien Korelasi Kemandirian di Bidang } \\
\text { (Correlation coeficient in field of) }\end{array}$} \\
\hline & & $\begin{array}{l}\text { Ekonomi } \\
\text { (Economy) }\end{array}$ & $\begin{array}{l}\text { Sosial Budaya } \\
\text { (Social-cultural) }\end{array}$ & $\begin{array}{r}\text { Kemandirian } \\
\text { (Self-reliance) }\end{array}$ \\
\hline Umur (age) & .074 & -.014 & .058 & .032 \\
\hline Pendidikan formal (education) & $.405^{* *}$ & $.295^{* *}$ & .153 & $.286^{* *}$ \\
\hline Pelatihan (training) & $.353^{* *}$ & $.491^{* *}$ & $.529^{* *}$ & $.544^{* *}$ \\
\hline Mata pencaharian (livelihoods) & .120 & .013 & .014 & .046 \\
\hline Pendapatan (income) & $.389^{* *}$ & $.362^{* *}$ & $.304^{* *}$ & $.385^{* *}$ \\
\hline Kepemilikan lahan (land ownership) & .143 & $.336^{* *}$ & .154 & $.233^{*}$ \\
\hline Jumlah tanggungan keluarga (household size) & .082 & .150 & .051 & .097 \\
\hline Etnis pemukim (etnic) & $.360^{* *}$ & .063 & .109 & $.204^{*}$ \\
\hline $\begin{array}{l}\text { Keikutsertaan dalam kelompok (membership in } \\
\text { community group) }\end{array}$ & $.624^{* *}$ & $.395^{* *}$ & $.543^{* *}$ & $.570^{* *}$ \\
\hline Keterdedahan informasi (information exposure) & $.357^{* *}$ & $.408^{* *}$ & $.597^{* *}$ & $.482^{* *}$ \\
\hline
\end{tabular}

Keterangan (Remarks):

*Korelasi signifikan pada $\alpha=0.05$ (correlations is significant at level 0.05 sig. two tailed)

** Korelasi signifikan pada $\alpha=0.01$ (correlations is significant at level 0.01 sig. two tailed) 
perubahan dalam masyarakat yang tinggal disekitar kawasan dan sebagian besar berbatasan langsung dan berinteraksi dengan kawasan, sebagai hasil/dampak kegiatan pemberdayaan dalam pemenuhan kebutuhan hidupnya. Interaksi positif dan akses bagi masyarakat dalam zona tertentu di taman nasional diharapkan dapat meningkatkan kemandirian mereka. Hasil penelitian disajikan dalam tabel berikut:
Hasil penelitian menunjukkan adanya keeratan hubungan antara faktor interaksi dan akses masyarakat terhadap kemandirian masyarakat dalam mengembangkan perilaku di bidang ekologi, ekonomi dan sosial budaya. Tingkat ketergantungan terhadap kawasan mempunyai korelasi sangat signifikan dengan kemandirian dalam kategori keeratan hubungan yang kuat. Hal ini berarti bahwa semakin rendah tingkat ketergantungan

Tabel 3. Hubungan interaksi dan akses terhadap taman nasional dengan kemandirian masyarakat Table 3. Correlation of interaction and access to national park toward community sustainability

\begin{tabular}{|c|c|c|c|c|}
\hline \multirow{2}{*}{$\begin{array}{l}\text { Sub Variabel } \\
\text { (Sub Variables) }\end{array}$} & \multirow{2}{*}{$\begin{array}{l}\text { Ekologi } \\
\text { (Ecology) }\end{array}$} & \multicolumn{3}{|c|}{$\begin{array}{l}\text { Koefisien Korelasi Kemandirian di Bidang } \\
\text { (Correlation coeficient in field of) }\end{array}$} \\
\hline & & $\begin{array}{l}\text { Ekonomi } \\
\text { (Economy) }\end{array}$ & $\begin{array}{l}\text { Sosial Budaya } \\
\text { (Social-cultural) }\end{array}$ & $\begin{array}{l}\text { Kemandirian } \\
\text { (Self-reliance) }\end{array}$ \\
\hline $\begin{array}{l}\text { Ketergantungan terhadap TNBBS (dependence } \\
\text { community toward BBSNP) }\end{array}$ & $.461^{* *}$ & $.400^{* *}$ & $.487^{* *}$ & $.489^{* *}$ \\
\hline $\begin{array}{l}\text { Keterlibatan masyarakat dalam program } \\
\text { pemberdayaan (community involvement to empowerment } \\
\text { program) }\end{array}$ & $.623^{* *}$ & $.439^{* *}$ & $.566^{* *}$ & $.593^{* *}$ \\
\hline $\begin{array}{l}\text { Manfaat langsung TNBBS (perceived direct benefit } \\
\text { to BBSNP) }\end{array}$ & $.591^{* *}$ & $.599^{* *}$ & $.603^{* *}$ & $.665^{* *}$ \\
\hline $\begin{array}{l}\text { Akses dalam kegiatan TNBBS (comunity acces } \\
\text { toward BBSNP) }\end{array}$ & $.703^{* *}$ & $.651^{* *}$ & $.780^{* *}$ & $.823^{* *}$ \\
\hline $\begin{array}{l}\text { Interaksi dan akses terhadap TNBBS } \\
\text { (interaction and access toward BBSNP) }\end{array}$ & $.745^{* *}$ & $.703^{* *}$ & $.780^{* *}$ & $.823^{* *}$ \\
\hline
\end{tabular}

Keterangan (Remarks):

*Korelasi signifikan pada $\alpha=0.05$ (correlations is significant at level 0.05 sig. two tailed)

$* *$ Korelasi signifikan pada $\alpha=0.01$ (correlations is significant at level 0.01 sig. two tailed)

masyarakat terhadap kawasan yang berarti semakin baik inter-aksi masyarakat dengan kawasan, maka terdapat kecenderungan semakin baik pula tingkat ke-mandiriannya.

Tuntutan pemenuhan kebutuhan dan keterbatasan lahan menyebabkan masyarakat memanfaatkan kawasan hutan. Dengan adanya kegiatan pemberdayaan dan seiring kesadaran masyarakat yang semakin baik, saat ini aktifitas tersebut sudah berkurang, meskipun berbagai aktifitas lain untuk memenuhi kebutuhan masih dilakukan, antara lain mengambil berbagai hasil hutan untuk memenuhi kebutuhan mulai dari kebutuhan akan air, pakan ternak, kayu bakar, berburu, mengambil anggrek, tanaman obat.

Manfaat langsung keberadaan taman nasional yang dirasakan oleh masyarakat mempunyai korelasi sangat signifikan dengan keeratan hubungan kuat. Manfaat langsung yang dirasakan ini berkorelasi positif dengan kemandirian. Hal ini berarti semakin besar manfaat langsung yang dirasakan, maka diharapkan masyarakat akan semakin terdorong untuk mengembangkan perilaku kemandirian. Manfaat taman nasional terdiri dari manfaat ekonomi, ekologi dan sosial budaya. Namun demikian, sebagaimana di ketahui bahwa kebutuhan masyarakat di sekitar kawasan taman nasional adalah kebutuhan untuk waktu sekarang. Berdasarkan hal tersebut, upaya untuk meningkatkan manfaat langsung yang dirasakan masyarakat dengan adanya taman nasional perlu dipertimbangkan dalam pengelolaannya, sehingga terjadi interaksi positif antara masyarakat dengan kawasan. Selama ini TNBBS juga telah melakukan upaya tersebut, misalnya dengan pemanfaatan sumber daya kawasan yang langsung dapat dirasakan manfaatnya oleh masyarakat seperti pemanfaatan air untuk mikrohidro, penanaman batas kawasan dengan hijauan makanan ternak dan sebagainya. Upaya ini perlu terus ditingkatkan, 
misalnya dengan pengembangan usaha produktif ke arah aneka usaha kehutanan. Dengan demikian masyarakat akan lebih merasakan manfaat langsung kawasan TNBBS, sehingga diharapkan kedekatan dan rasa memiliki akan mendorong perilaku positif dalam meningkatkan kesejahteraan dengan mempertimbangkan kelestarian kawasan.

Dalam penelitian ini keterlibatan dalam kegiatan pemberdayaan yang dilakukan oleh TNBBS mempunyai korelasi positif sangat signifikan terhadap kemandirian. Keterlibatan masyarakat dalam konteks penelitian ini lebih ditekankan pada dimensi waktu, yaitu berapa lama responden terlibat dalam pemberdayaan masyarakat. Sebagaimana hasil penelitian Hashemi et al. (1996) yang diacu dalam Herawati (2012), bahwa lamanya responden menjadi anggota pemberdayaan berpengaruh signifikan terhadap beberapa indikator pemberdayaan, seperti kemandirian dan keterlibatan dalam pengambilan keputusan. Masyarakat yang telah lama terlibat dalam kegiatan pemberdayaan mempunyai tingkat partisipasi dan kemandirian yang lebih baik dibandingkan dengan yang belum lama terlibat. Hal ini dapat dipahami karena semakin lama masyarakat terlibat dalam kegiatan maka baik pengetahuan, wawasan, sikap dan tindakan mereka akan meningkat ke arah yang positif.

Dari hasil analisis, akses masyarakat dalam kegiatan taman nasional baik dalam kegiatan pemberdayaan maupun kegiatan-kegiatan taman nasional lainnya mempunyai korelasi positif sangat signifikan dengan tingkat keeratan hubungan sangat kuat dengan kemandirian masyarakat. Dengan demikian, dengan memperbesar akses masyarakat terhadap kegiatan-kegiatan taman nasional baik dalam hal pelestarian hutan maupun pemberdayaan diharapkan akan mendorong partisipasi dan kemandirian masyarakat ke arah yang lebih baik.

Meningkatkan pemberian akses kepada masyarakat dalam pengelolaan taman nasional berarti memberikan kepercayaan dan tanggungjawab kepada masyarakat untuk berpartisipasi didalamnya. Dalam pemberdayaan MDK, misalnya dengan fasilitasi penyuluh, masyarakat diberi akses dalam perencanaan, pelaksanaan, pemanfaatan dan monitoring evaluasi. Dengan demikian masyarakat mempunyai akses terhadap semua proses dalam pemberdayaan. Hal ini diharapkan akan mendorong masyarakat untuk merasa memiliki dan membutuhkan, dan bukan hanya sebagai objek penerima. Secara keseluruhan interaksi dan akses masyarakat terhadap taman nasional mempunyai korelasi sangat signifikan dengan kemandirian $(\mathrm{r}=0.823)$.

\section{Upaya Penyempurnaan Program Pember- dayaan Melalui Pendekatan Pemberdayaan}

Pendekatan yang sesuai diharapkan dapat mengembangkan perilaku positif masyarakat sehingga tahu, mau dan mampu melaksanakan kegiatan dalam rangka konservasi kawasan dan sekaligus dapat bermanfaat bagi peningkatan kesejahteraan masyarakat. Upaya ini salah satunya ditempuh melalui pemberian informasi sebanyakbanyaknya kepada masyarakat dan mengajak mereka untuk selalu tanggap dan peduli terhadap lingkungan di sekitar mereka dalam hal ini TNBBS.

Dari hasil analisis, semua sub variabel dalam pendekatan pemberdayaan mempunyai korelasi positif sangat signifikan dengan kemandirian. Adanya korelasi tersebut mengindikasikan bahwa pemberdayaan akan berdampak positif dengan diterapkannya pendekatan pemberdayaan yang tepat. Hubungan pendekatan pemberdayaan dengan kemandirian masyarakat disajikan dalam Tabel 4.

Faktor kesepahaman mempunyai korelasi positif sangat signifikan dengan tingkat keeratan hubungan yang kuat dengan kemandirian masyarakat. Kesepahaman dalam konteks ini adalah upaya sosialisasi yang dilakukan oleh pihak pengelola berkaitan dengan MDK dan seberapa jauh masyarakat sasaran memahaminya. Hal ini berarti bahwa semakin masyarakat memahami mengenai kegiatan dimana mereka terlibat di dalamnya, maka dapat diharapkan semakin besar pula partisipasi serta kemandirian mereka.

Pemberdayaan masyarakat daerah penyangga sekitar TNBBS tidak hanya untuk meminimalisir terjadinya kerusakan sumberdaya hutan dan ekosistemnya akibat perambahan dan tindak ilegal lainnya namun juga diarahkan sebagai upaya untuk memberikan kesempatan, kemudahan dan fasilitasi pada masyarakat agar secara mandiri tau, sadar, mau dan mampu mengembangkan potensi yang dimiliki dengan senantiasa memperhatikan upaya pelestarian sumberdaya alam dan lingkungan hidupnya.

Partisipasi bagi TNBBS adalah mengupayakan dan mengakomodir hal tersebut berdasarkan 
pengakuan bahwa masyarakat memiliki potensi pengetahuan, kemampuan serta kearifan untuk memanfaatkan sumberdaya hutan secara lestari. TNBBS mencoba memberi tanggungjawab melalui pemberdayaan sebagai bentuk partisipasi masyarakat sekitar. Namun demikian masyarakat tidak selalu berpijak dari hal yang sama. Adanya ketergantungan yang relatif tinggi dari masyarakat terhadap pendampingan mengindikasikan masyarakat belum siap untuk diberi tanggung jawab itu. Di samping itu masih banyak masyarakat yang menganggap kegiatan MDK sebagai kewajiban dari pemerintah atau kompensasi semata dari pihak TNBBS karena masyarakat tidak boleh merusak hutan, pemusnahan tanaman pada lahan perambahan ataupun imbalan atas perilaku mereka dalam membantu program TNBBS. Adanya pandangan demikian paling tidak akan mempengaruhi masyarakat terutama dalam keikutsertaan mereka dalam program terkait dengan apakah mereka menganggap pemberdayaan sebagai proyek semata ataukah sudah menjadi kebutuhan.

Kelembagaan mempunyai korelasi positif sangat signifikan dengan keeratan hubungan yang kuat. Kelembagaan dalam hal ini meliputi kelembagaan internal dalam MDK termasuk aturanaturan yang jelas mengenai pelaksanaannya mau- pun adanya lembaga lain yang mendukung. Dalam kegiatan pemberdayaan, termasuk MDK, dimana kawasan mempunyai wilayah lintas provinsi dan juga kompleksitas permasalahan hutan dengan masyarakat sendiri, maka diharapkan pelaksanaannya mendapat dukungan bukan saja dari pihak pengelola tetapi juga lembaga ataupun instansi lain yang terkait dengan kegiatan pemberdayaan.

Selain itu, peran penyuluh sebagai fasilitator/ penyuluh sebagai mata rantai komunikasi yang menghubungkan sistem sosial yang mempelopori perubahan atau sumber informasi dengan sistem sosial masyarakat yang dibinanya menunjukkan adanya hubungan positif sangat signifikan dengan tingkat keeratan hubungan kuat dengan kemandirian. Dalam konteks ini korelasi tersebut berkaitan dengan kemampuan yang dimiliki fasilitator, meliputi kedekatan dengan masyarakat, kemampuan dalam membangun kesepakatan bersama, mengembangkan hubungan dan membangun kemitraan, memberikan saran, masukan dan informasi bermanfaat serta keterampilan teknis yang dimiliki.

Proses pembelajaran dalam pendampingan yang berjalan baik merupakan kunci keberhasilan program. Berdasarkan hasil analisis, pendampingan mempunyai hubungan positif sangat signifikan dengan tingkat keeratan

Tabel 4. Hubungan pendekatan pemberdayaan dengan kemandirian masyarakat Table 4. Correlation of empowerment approach toward community sustainability

\begin{tabular}{|c|c|c|c|c|}
\hline \multirow{2}{*}{$\begin{array}{l}\text { Sub Variabel } \\
\text { (Sub Variables) }\end{array}$} & \multirow{2}{*}{$\begin{array}{l}\text { Ekologi } \\
\text { (Ecology) }\end{array}$} & \multicolumn{3}{|c|}{$\begin{array}{l}\text { Koefisien Korelasi Kemandirian di Bidang } \\
\text { (Correlation coeficient in field of) }\end{array}$} \\
\hline & & $\begin{array}{l}\text { Ekonomi } \\
\text { (Economy) }\end{array}$ & $\begin{array}{l}\text { Sosial Budaya } \\
\text { (Social-cultural) }\end{array}$ & $\begin{array}{c}\text { Kemandirian } \\
\text { (Self-reliance) }\end{array}$ \\
\hline Kesepahaman (understanding) & $.625^{* *}$ & $.437^{* *}$ & $.537^{* *}$ & $.575^{* *}$ \\
\hline Kelembagaan (organizational) & $.416^{* *}$ & $.395^{* *}$ & $.330^{* *}$ & $.435^{* *}$ \\
\hline Fasilitator (facilitator) & $.656^{* *}$ & $.603^{* *}$ & $.705^{* *}$ & $.717^{* *}$ \\
\hline Pendampingan (assistance) & $.635^{* *}$ & $.727^{* *}$ & $.694^{* *}$ & $.777^{* *}$ \\
\hline $\begin{array}{l}\text { Bentuk kegiatan pemberdayaan (form of } \\
\text { empowerment activity) }\end{array}$ & $.539^{* *}$ & $.720^{* *}$ & $.600^{* *}$ & $.708^{* *}$ \\
\hline Jejaring kerja dan kemitraan (networking) & $.449^{* *}$ & $.541^{* *}$ & $.530^{* *}$ & $.567^{* *}$ \\
\hline $\begin{array}{l}\text { Monitoring dan evaluasi (monitoring and } \\
\text { evaluation) }\end{array}$ & $.402^{* *}$ & $.523^{* *}$ & $.550^{* *}$ & $.565^{* *}$ \\
\hline $\begin{array}{l}\text { Pendekatan pemberdayaan (empowerment } \\
\text { approach) }\end{array}$ & $.712^{* *}$ & $.771^{* *}$ & $.781^{* *}$ & $.842^{* *}$ \\
\hline
\end{tabular}

Keterangan (Remarks):

${ }^{*}$ Korelasi signifikan pada $\alpha=0.05$ (correlations is significant at level 0.05 sig. two tailed)

** Korelasi signifikan pada $\alpha=0.01$ (correlations is significant at level 0.01 sig. two tailed) 
hubungan sangat kuat dengan kemandirian masyarakat. Pendampingan dalam hal ini meliputi keberlanjutan interaksi dengan masyarakat, kesesuaian tujuan pember-dayaan MDK dengan masyarakat, proses komunikasi, manfaat yang dicapai dan pembelajar-an yang terjadi dalam pemberdayaan MDK. Disadari bahwa pemberdayaan MDK bukanlah kegiatan yang bersifat instan. Pendampingan tidak bisa serta merta berhenti ketika proyek selesai, tetapi harus berkelanjutan mulai dari tahap prakondisi, persiapan, pelaksanaan, dan evaluasi sehingga masyarakat memiliki kemandirian yang mantap.

Dari hasil penelitian, masyarakat mempunyai ketergantungan terhadap pendampingan. Adanya ketergantungan yang relatif tinggi dari masyarakat terhadap pendampingan mengindikasikan masyarakat belum siap untuk menerima tanggung jawab dalam kegiatan pemberdayaan. Sebagian masyarakat menganggap bahwa program pemberdayaan adalah kewajiban pemerintah atau kompensasi ataupun imbalan atas perilaku mereka karena tidak boleh masuk/mengganggu kawasan.

Selain itu, masyarakat sebagai penerima manfaat kegiatan pemberdayaan bukan hanya dihadapkan pada masalah keterbatasan sumberdaya, tetapi juga masalah modal, pemasaran, kelembagaan kelompok, kemitraan keahlian teknis dan sebagainya. Dengan demikian pendampingan perlu dilakukan secara berkelanjutan untuk mengantisipasi dan memotivasi masyarakat untuk memecahkan masalah keterbatasan tersebut. Semakin baik pendampingan yang dilakukan, maka diharapkan akan semakin efektif kegiatan pemberdayaan.

Bentuk kegiatan pemberdayaan mempunyai korelasi positif sangat signifikan dengan tingkat keeratan hubungan yang kuat dengan kemandirian masyarakat. Dalam konteks penelitian ini, bentuk kegiatan pemberdayaan yang seimbang dalam bentuk fisik, didukung oleh peningkatan kapasitas sesuai dengan kebutuhan masyarakat, penguatan kelembagaan, dan penguatan jaringan kemitraan serta monitoring dan evaluasi sesuai dengan yang dibutuhkan masyarakat sasaran serta kondisi lokal setempat diharapkan dapat mendukung keberhasilan pemberdayaan.

Masyarakat Sukaraja pada umumnya mengharapkan kegiatan peningkatan kapasitas melalui pelatihan-pelatihan agar dapat mengelola kegiatan dengan lebih baik, sedangkan masyarakat Kubu
Perahu mengharapkan adanya kegiatan yang sesuai dengan potensi yang mereka miliki. Saat ini kegiatan MDK di Kubu Perahu difokuskan pada kegiatan budidaya ikan dengan pertimbangan persediaan air yang melimpah. Kegiatan ini merupakan bentuk kegiatan yang telah disetujui oleh masyarakat. Namun dalam perkembangannya ketika ternyata budidaya ikan tidak memberikan hasil sesuai yang diharapkan, masyarakat tidak bersemangat lagi mengerjakannya dan mulai melirik kegiatan lain yang lebih menjanjikan secara ekonomis. Bukan tidak mungkin, kondisi demikian akan mendorong masyarakat untuk kembali melakukan tindakan ilegal terhadap hutan. Dengan demikian meskipun keputusan jenis bantuan berdasarkan atas permintaan masyarakat, tetapi tetap harus dikaji lebih lanjut bagaimana prospek ke depan, kendala yang harus dihadapi, pengaruhnya terhadap masyarakat, bagaimana pemasarannya dan sebagainya.

Jejaring kerja dan kemitraan mempunyai hubungan positif sangat signifikan dengan tingkat keeratan hubungan yang kuat dengan kemandirian masyarakat. Hal ini berarti bahwa dengan pengembangan jejaring kerja dan kemitraan yang baik diharapkan kegiatan pemberdayaan akan lebih efektif. Sebagaimana telah disebutkan bahwa masyarakat mempunyai keterbatasan dalam berbagai hal, oleh karenanya mereka perlu pendampingan. Pendamping, dalam hal ini penyuluh juga mempunyai keterbatasan, yang dalam penelitian ini terutama adalah dalam hal jumlah dan tenaga serta keahlian teknis.

Keterbatasan bukan hanya aset sumberdaya alam termasuk lahan tetapi juga sering berbagai keterbatasan lainnya seperti keterbatasan skala usaha, manajemen, modal, teknologi, keahlian dan pemasaran. Sementara itu, biasanya aset teknologi, permodalan dan manajemen yang baik dimiliki oleh sektor ekonomi skala besar, sektor perbankan/lembaga keuangan dan sejenisnya. Kondisi demikian memerlukan koordinasi yang baik dalam menjalin kemitraan dan jaringan kerja agar dapat mengantisipasi keterbatasan yang ada.

Monitoring dan evaluasi memiliki korelasi positif sangat signifikan dengan tingkat keeratan hubungan yang kuat dengan kemandirian masyarakat. Dengan melaksanakan monitoring dan evaluasi maka diharapkan akan lebih mendorong kegiatan agar lebih terarah dan sesuai dengan tujuan. 
Dengan demikian faktor pendekatan pemberdayaan secara keseluruhan mempunyai korelasi sangat signifikan dengan kemandirian $(\mathrm{r}=0.842)$.

\section{KESIMPULAN DAN SARAN}

\section{A. Kesimpulan}

Pelaksanaan kegiatan pemberdayaan Model Desa Konservasi (MDK) di TNBBS secara umum dapat dikatakan telah memberikan dampak bagi kemandirian masyarakat meskipun belum optimal sebagaimana diharapkan. Kemandirian masyarakat dalam mengembangkan perilaku kemandirian di bidang ekologi, ekonomi dan sosial budaya dalam aspek kognitif, afektif dan psikomotorik berada dalam kategori baik. Hal ini berarti bahwa masyarakat menjadi lebih tau, mau dan mampu melaksanakan berbagai hal positif terkait kelestarian kawasan dan peningkatan kesejahteraan mereka.

Faktor-faktor yang mempunyai korelasi/ hubungan dengan kemandirian masyarakat adalah sebagai berikut: (1) Karakteristik sosio-demografi yang terdiri dari pendidikan formal, pelatihan, pendapatan, kepemilikan lahan, asal etnis, keikutsertaan dalam kelompok, dan keterdedahan terhadap informasi mempunyai korelasi positif sangat signifikan kemandirian, sedangkan umur, mata pencaharian, dan jumlah tanggungan keluarga tidak mempunyai korelasi dengan kemandirian; (2) Interaksi dan akses terhadap taman nasional, secara keseluruhan mempunyai korelasi positif sangat signifikan dengan kemandirian; dan (3) Pendekatan pemberdayaan yang dilakukan oleh TNBBS mempunyai korelasi positif sangat signifikan dengan kemandirian.

\section{B. Saran}

Adanya korelasi antara karakteristik sosiodemografi, interaksi dan akses terhadap taman nasional serta pendekatan pemberdayaan terhadap kemandirian masyarakat sebagai dampak kegiatan pemberdayaan MDK di TNBBS, mengindikasikan bahwa meningkatkan pemahaman terhadap berbagai faktor tersebut serta menerapkan pendekatan pemberdayaan yang sesuai, merupakan hal penting dan relevan dalam upaya meningkatkan dampak positif pemberdayaan MDK di TNBBS.
Upaya untuk meningkatkan kemandirian sebagai dampak pemberdayaan MDK di TNBBS dapat dilakukan dengan mempertimbangkan halhal sebagai berikut: (1) Melaksanaan tahap-tahap pengembangan MDK mulai dari prakondisi, persiapan dan perencanaan, pelaksanaan, monitoring dan evaluasi; (2) Melaksanakan koordinasi, sosialisasi dan pendampingan secara intensif dan berkesinambungan; (3) Meningkatkan bentuk kegiatan untuk meningkatkan pengetahuan substansif yang relevan dan tidak hanya bantuan dalam bentuk fisik; (4) Meningkatkan manfaat langsung TNBBS bagi masyarakat melalui pengembangan hasil hutan non kayu dan usaha produktif bidang kehutanan; (5) Mengembangkan upaya melibatkan masyarakat dalam pengelolaannya, sesuai dengan zona yang telah ditetapkan; (6) Optimalisasi fungsi lembaga penelitian, untuk mengembangkan inovasi dan menciptakan kreativitas baru berkaitan dengan pengelolaan usaha berbasis kehutanan; dan (7) Bagi masyarakat, upaya pemberdayaan hendaknya didukung melalui peran aktif sehingga peningkatan akses timbal balik dapat mencapai tujuan (dampak positif) yang diharapkan.

\section{DAFTAR PUSTAKA}

Agbogidi OM., Okonta, BC., Dolor, DE. 2005. Participation of Rural Women in Sustainable Forest Management and Development. Okoko E (inputs), Adekline V, Adeduntan S (editors). Environment Sustainability and Conserve in Nigeria: 264-270. Akure. Jubee Niyi Publisher.

Agbogidi, OM., Ofuoku, AU. 2009. Forestry Extension: Implications for Forest Protection [review]. International Journal of Biodiversity and Conservation 1 (5): 98-104.

Borrini-Feyerabend, G., Kothari, A., Oviedo, G. 2004. Indigenous and Local Communities and Protected Areas Towards Equity and Enhanced Conservation (Guidance on Policy and Practice for Co-managed Protected Areas and Community Conserved Areas). Bassi M et al., (inputs); Phillips A (Editor). World Commission on Protected Areas (WCPA). IUCN - The World 
Conservation Union. Best Practice Protected Area Guidelines Series 11.

[BTNBBS] Balai Besar Taman Nasional Bukit Barisan Selatan. 2010. Penyusunan Master Plan Penanganan Perambahan TNBBS Tanggamus-Lampung: Balai Besar TNBBS.

[BTNBBS] Balai Besar Taman Nasional Bukit Barisan Selatan. 2011. Statistik Taman Nasional Bukit Barisan Selatan tahun 2010. Tanggamus - Lampung: Balai Besar TNBBS.

[Dephut] Departemen Kehutanan. 1999. Undangundang Republik Indonesia Nomor 41 Tahun 1999 tentang Kehutanan. Jakarta: Departemen Kehutanan.

- 2006. Peraturan Menteri Kehutanan Nomor 56/Menhut-II/2006 tentang Pedoman Zonasi Taman Nasional. Jakarta: Departemen Kehutanan.

. 2009. Laporan Nasional Pelaksanaan Model Desa Konservasi (MDK). Bogor: Direktorat Pemanfaatan Jasa Lingkungan dan Wisata Alam (PJLWA), Direktorat Jenderal perlindungan Hutan dan Konservasi Alam, Departemen Kehutanan.

Effendi, R., Bangsawan, I., Muttaqin, MZ. 2007. Kajian Pola-Pola Pemberdayaan Masyarakat Sekitar Hutan Produksi dalam Mencegah Illegal Logging. Jurnal Penelitian Sosial dan Ekonomi Kehutanan 4(4):321- 340

Guthiga, PM. 2008. Understanding Local Communities Perceptions of Existing Forest Management Regimes of a Kenyan Rainforest. International Journal of Social Forestry (IJSF) 1(2):145-166.

Herawati, T. 2012. Manajemen Sumberdaya Keluarga dan Ketahanan Keluarga Peserta Pemberdayaan Masyarkat di Pedesaan (Kasus di Kabupaten Bogor) [disertasi]. Bogor: Sekolah Pascasarjana, Institut Pertanian Bogor.

[Kemenhut] Kementerian Kehutanan. 2011a. Pedoman Umum Pengembangan Perhutanan Masyarakat Pedesaan Berbasis
Konservasi. Jakarta: Kementerian Kehutanan.

. 2011b. Peraturan Menteri Kehutanan Republik Indonesia Nomor: P. 16/Menhut-II/2011 tentang Pedoman Umum Program Nasional Pemberdayaan Masyarakat Mandiri Kehutanan. Jakarta: Kementerian Kehutanan.

Kinnaird, MF., Sanderson, EW., O'Brien, TG., Wibisono, HT., Woolmer, G. 2003. Deforestation Trends in a Tropical Landscape and Implications for Endangered Large Mammals. Conservation Biology 17: 245-257.

Page, N., Szuba, CE. 1999. Empowerment: What is it? [commentary] Journal of Extension 37(5).

Riyanto, B. 2005. Pemberdayaan Masyarakat Sekitar Hutan dalam Perlindungan Kawasan Pelestarian Alam. Bogor: Lembaga Pengkajian Hukum Kehutanan dan Lingkungan. 2005.

Robertson, J., Lawes, M. 2005. User Perceptions of Conservation and Participatory Management of Igxalingenwa Forest, South Africa. Environmental Conservation 32(1):64-75.

Santosa, I. 2004. Pemberdayaan Petani Tepian Hutan Melalui Pembaharuan Perilaku Adapatif [disertasi]. Bogor: Sekolah Pascasarjana, Institut Pertanian Bogor.

Sumardjo. 2012. Review dan Refleksi Model Penyuluhan dan Inovasi Penyuluhan Masa Depan [makalah]. Seminar Nasional Membangun Penyuluhan Masa Depan yang Berkeadilan dan Menyejahterakan, 20 Februari 2012. Bogor: Ilmu Penyuluhan Pembangunan, Sekolah Pascasarjana, Institut Pertanian Bogor.

Wiggins, S., Marfo, K., Anchirinah, V. 2004. Protecting the Forest or the People? Environmental Policies and Livelihoods in the Forest Margins of Southern Ghana. World Development 32(11):1939-1955. 